\title{
The City in Literature: The Image of Lagos City in Lagos Noir
}

\author{
Morolake Dairo \\ School of Media and Communication, Pan-Atlantic University, Main Campus, \\ Km 52 Lekki-Epe Expressway, Lagos, Nigeria
}

\begin{abstract}
The media plays a key role in positioning places. Movies, music, magazines and books have been used to create images of various cities for both residents and visitors alike. A closer look at literary texts will reveal that cities are a common feature in literature and they play a key role in setting the tone for the character and other elements in the text. Lagos city has been featured in numerous literary works and it is important to examine the representations of the city, to understand how it can impact the positioning of the city in the minds of readers and prospective visitors. This study examines the portrayal of Lagos city in literature by analysing three stories in the fictional collection, Lagos Noir. Leveraging the city brand hexagon model, the various themes observed in these stories were examined using the content analysis method. Findings from this research show that the representation of Lagos in Lagos Noir is based on the socio-economic realities in the city and Nigeria in general. Since literature is mostly a reflection of existing elements of the city, the onus lies on the city administrators to ensure that the socio-economic and infrastructural facilities remain attractive to all its stakeholders, including the literary community.
\end{abstract}

Keywords: Lagos city, Lagos Noir, City Branding, Place Branding

DOI: $10.7176 / \mathrm{JTHS} / 59-01$

Publication date:October $31^{\text {st }} 2021$

\section{Introduction}

Stories and cities have a compulsive symbiotic relationship; the characters must exist within a space and the city must be woven around a story; the change of location can determine the breadth and width of a character (Spinks, 2016). Adichie's Half of a Yellow Sun will take you on a time travel to civil war Nigeria. The Harry Potter series will get you thinking about the city of London. Agatha Christie's novels have been well known to take a twist around famous Parisian locations or global train stations. Places usually form the backdrop for characters and plots; mostly determining and winding with the twists as the stories develop. Some cities have made tourism out of literary characters and authors. For example, Shakespeare's hometown - Stratford-Upon-Avon - has become a tourist attraction (Alen, 2009; National Geographic Traveler Magazine, 2011).

Howe (1971) explains the impact of the city on literature in various ways from an urban, sophisticated and modernistic perspective, separating the city from the town or the village. Firstly, as a presence that majorly influences narration styles. As the urban location can change the discourse patterns. Secondly, it permits complex social relationships when compared to other locations such as towns. Thirdly, the city has led to the development of new genres such as surrealism and fantasy as obvious in novels such as The Hunger Games series. Fourthly, the city impacts the type of language employed in books and gives the reader an incline into character-revealing elements such as status and transition.

Books such as Ulysses by James Joyce and Manhattan Transfer by John Dos Passos give a visual introduction to the city of Dublin and New York respectively, as Malone (2018) describes such books as "eternal text cities" for the audience to observe. Beyond viewing the city as a setting, the author views the city as a personality - a character speaking its own language and acting out its own scenes.

Books impact places in various ways. They act as a historical document for reference; allowing readers in the current era access into history. Secondly, they act as prophetic documents - pre-empting the future and reconstructing the city through fantasy and surreal interpretations. Thirdly, they bridge the gap for non-residents of the city, those who have never visited can imagine and reconstruct images of the city through the literary and visual descriptions of a city and its elements (Malone, 2018).

It is important to investigate the representation of cities in the media, as much as how the behaviour and happenings of city dwellers and visitors influence stories and content, the image of the city can influence the reader's perception about the city (Akande, 2016). This study views the city from the perspective of a place; a combination of its urban and its space elements - the backdrop of the story. While most studies in this sphere have explored the city from solely a literary and symbolic point of view, this research will focus on city branding and will utilize the city branding index in determining how the city has been represented in literary texts.

\subsection{Media Representations and the City}

There is extensive literature on the relationship between movies and cities. The TV series, Sex and the city is a good example of how media effectively positioned New York fashion as one of the leading fashion industries in 
the world using the main character, Carrie Bradshaw and her friends to present New York from a fashionable perspective to the audience (Bruzzi \& Gibson, 2004). Establishing scenes in the movie include images from the Twin Towers, the Empire State Building and the Brooklyn Bridge, affording viewers who had never visited the city to envision the corners, restaurants, hotels and tourist haven of New York through a screen. In the book turned movie, White Tiger, the author presents Delhi, a city in India in its unfiltered form through the character of the protagonist, Balram, showing the bi-polar opposites of the rural and urban settlements ridden with corruption, poverty and underdevelopment (Pasari, 2015).

Music videos and lyrics have also become channels and transmission of pop culture, cultural values and urban identities. The chorus in the Lagos Party song by Nigerian artiste, Banky W resonates the nightlife common to Lagos (Wellington, 2010) as stated thus; "Ain't no party like a Lagos party, Cause a Lagos party we don't bother nobody, We just throw our hands up, Drinks in our cups..." Some of the lyrics from the verses also call out the hustle spirit associated with the city of Lagos with the words, "city of hustlers, home of the bravest."

Likewise, the song, New York, Empire State of Mind sung by Alicia Keys and Jay Z is an ode to the cliché American dream of opportunity and power (Makmun \& Nuraeni, 2018) as evident in the chorus, "In New York! Concrete jungle where dreams are made of, there's nothing you can't do, Now you're in New York! These streets will make you feel brand new, big lights will inspire you...". Like it or not, such lyrics and sceneries of the city reflect the values of American citizens and export certain ideologies to tourists and immigrants.

Digitization has further bridged the global lines between locals, visitors and a city through images, videos, hashtags and social media activities, that link individuals from Soweto to individuals in Tokyo through the click of the share button, like button and comment section on social media platforms. City administrators now employ social media to champion social causes, campaign for votes and announce urban policies and laws (Kia, Latifi, Rasooli, \& Kazemnia, 2016). Beyond citizen participation, social media has also been used in branding and positioning cities on a competitive scale to attract talent, investors, global students and tourists. Information on websites, Instagram, Twitter and Facebook accounts are replacing and supporting traditional tourism brochures and University prospectus with more vibrant images, videos, live reviews and celebrity influencers (Bjorner, 2013). A keyword search on various global cities will reveal tourist videos, video blogs and topics on the top 10 Instagrammable cities to visit. Without a doubt, social media has become a guide for visitors, investors and immigrants in determining their city of visit or study (Liu, Mehraliyev, \& Liu, 2019).

While this section has explored various types of media including movies, music and social media and their relationship with cities, this study is focused on how cities are reflected in fiction literature with the scope of this study limited to Lagos city in Nigeria.

\section{Literature Review}

Lagos continues to be a city of focus for writers. Authors of Nigerian origins such as Leye Adenle, Oyinkan Braithwaite, Toni Kan, Sefi Atta and Teju Cole have set it as a vivid backdrop to their stories (Ocran, 2014). Bures (2007) describes Lagos as "a huge Dickensian space full of heartbreak and humour and millions of souls putting themselves up against the hard edge of the world..." French (2020) describes Lagos as the capital of Noir drawing from the writings of veteran writers such as Cyprian Ekwensi, Chris Abani and newcomers such as Leye Adenle.

The advancement of the city of Lagos from pre-colonial to the post-independence era in Nigeria has been well-captured in literature. Akande (2016) reviewed two Nigerian novels, People of the City by Cyprian Ekwensi and Alpha Song involving the representation of the symbolic city in literature. According to the author, the city is viewed as a progressive move to become better and a place of desperation to make it by hook or crook (Iduma, 2020). However, Maik Nwosu the author of the Alpha Song balances the perception of the city as a place of doom with a positive plot.

In reality, Lagos city held the status of Capital of Nigeria before the current capital, Abuja claimed the position in 1991. However, Lagos has been described as the economic capital of Nigeria and a megacity (Emordi \& Osiki, 2008) with the availability of urban facilities such as potable water, modern housing and employment opportunities. Increasingly, there is an influx of multinationals as well as individuals from various Nigerian states moving into the city daily for the search of a "better life" (Akingbe \& Akwen, 2019). Now the city is home to a mixed population of indigenes from other Nigerian ethnic groups in addition to expatriates. However, history reveals that a sub-group from the Yorubas known as the Awori fishermen and farmers were the first settlers of Lagos city (Emordi \& Osiki, 2008).

The city has two major districts known as Lagos Mainland and Lagos Island, which are evident in the topographical distribution of the city which is surrounded by creeks. Historical sites such as the University of Lagos and the Murtala Muhammed International airport are situated on the Lagos Mainland, and Lagos Island is popular for the new coastal city project, Eko Atlantic City and beaches.

Despite its economic potential, the alarming rate in population growth is a challenge for the city and has become the largest city in Sub-Saharan Africa with a reported population of 14million people in 2021. By 2035, 
population growth is estimated at 24.4 million, yet in 1971 the city was reported to have about 1.3 million inhabitants (PopulationStat, 2021). The increase in population rates also mean constant competition for limited resources such as jobs, housing and businesses and while the city boasts of urban opportunities, there is a wide gap between the rich and the poor. The city is also popular for its traffic congestion with commuters spending between 30 mins and 3 hours on their daily commute and can spend as much as 30 hours weekly in traffic (Obi, 2018; Oni, Asenime, Ege, Efunshade, \& Oke, 2008; Ukpata \& Etika, 2012). In addition, Lagos has popularly been described as the capital of crimes such as 419 and internet fraud also known as the "Yahoo Yahoo"(French, 2020).

In its 2017 cost of living survey, Mercer ranked Lagos the $29^{\text {th }}$ most expensive city in the World (Premium Times Ng, 2017), yet the city is still lacking in areas of the availability of infrastructural facilities such as steady electricity, adequate security, substandard housing and efficient public transportation systems.

However, there are plans to rebuild and reposition the city as a resident and tourist delight, as evident in the Lagos State Development Plan (LSDP) 2012-2025, Ministry of Economic Planning and Budget, (2013) which explains the 2025 vision for Lagos state as "Africa's model megacity and global, economic and financial hub that is safe, secure, functional and productive”. In detailing the fulfilment of this vision, there is a focus on improving infrastructure such as water and sanitation, individual health, power supply amongst others; the basic infrastructure necessary for a city to remain attractive to inhabitants and inviting to tourists.

While the city of Lagos has been portrayed in various media including movies, music and global news from various positive and negative perspectives. This study is focused on how the city has been positioned in "dark" literature using the Lagos Noir as a case in point.

\subsection{The Novel, Lagos Noir}

The Noir Series launched in 2004 is published by Brooklyn-based, Akashic Books and is focused on literary works that border on urban and "political nonfiction." Its mission is focused on exposing unconventional writings (Akashic Books, 2021). Derived from the word Noir, a French word meaning Dark or Black; the series usually border on urban melancholic writings based in a particular city, as evident in collections such as Nairobi Noir, Alabama Noir, Boston Noir amongst others. The global Noir series is mostly focused on crime, strange, fatal and unsettling stories (Marcus, 2018) in whatever city of focus and this also influenced its selection as the case study. The global series weighs heavy on the realities, mostly dark that assail a city such as poverty, crime, dysfunction, corruption and violence (Shringarpure, 2020).

The Lagos Noir series is a one-stop collection of stories from Lagos written by a wide variety of authors from various genres. The 217-paged, Lagos Noir, published by Cassava Republic in Nigeria covers 13 stories partitioned into three sections; Cops \& Robbers; In a Family Way and Arrivals and Departures trailing political and social issues such as corruption, dysfunctional families and daily living in Nigeria's megacity, Lagos (Abani, 2018; French, 2020). The series is edited by Chris Abani, who can be described as a literary activist who has been jailed by the Nigerian military government for some of the political content in his novels (French, 2020).

The Lagos Noir Series starts with an introduction by the editor, Chris Abani titled "Lagos Never Sleeps". The phrase, "I am listening to Lagos with my eyes closed", ascribes the human senses as a channel to experience the city (Abani, 2018). Therefore, depending on the individual, the city can be seen, read, experienced, tasted, perceived and heard and all of these interactions influence the imagery affiliated with a place. The introduction goes further to give a background of the city of Lagos from its evolution as a pre-colonial settlement of the Aworis to a megacity that once was a colonial headquarters. To Chris Abani, Lagos is many things depending on who is experiencing the city. In his words, "the city of many names, that wears as many faces as there are people" (Abani, 2018) and the author goes further to set the background for stories in the Lagos Noir collection, with descriptions of the architecture, food, transport systems, tourist attractions and the economic berth that clearly distinguishes the rich from the poor and presents Lagos as a city of conflicting rights and wrongs.

\section{Theoretical Model: The City Brand Hexagon}

The concept of city branding evolved from the umbrella concept of place branding which focuses on the positioning of places including nations, towns, destinations and cities. The growing need for city administrators to brand their cities in the global sphere and compete internationally for talent, investors, residents and tourists has given more focus to this branch of place branding, which is the focus for this study. Various theories have been developed in this area, however, this study will be leveraging on the city brand hexagon model developed by Simon Anholt in 2006 (Anholt, 2006; Papp-Vary, 2011). So far, the metrics in the model has been used as an index in rating global cities annually. The city brand hexagon model is based on six categories, Presence, Place, Prerequisities, People, Pulse and Potential (Anholt, 2006; Papp-Vary, 2011.

The Presence metric is centred on the city's status in the global sphere and how it measures in various areas such as culture and governance. The second metric, Place explores the physical characteristics of the city in terms of architecture, weather, environmental factors amongst others. The third metric termed Pre-requisites is 
focused on the basic amenities available in the city in terms of healthcare, transportation and educational facilities, while People involves the residents of the city and their attitudes and behaviours in relation to their way of life. The Pulse of the city is focused on the creative aspect of the city and the leisure activities available to locals and visitors alike and the last metric, Potential examines the opportunities that the city poses in terms of employment and educational opportunities.

Originally these metrics are used in framing questions to elicit responses from individuals on their observation of cities, however, in this context, these metrics are used to guide the content analysis for this study. The analysis of the stories chosen from this novel is examined through the lens of these six metrics for cities. How do the authors position the city of Lagos using these metrics as a measurement and how does story-telling present geographical locations through the words of writers?

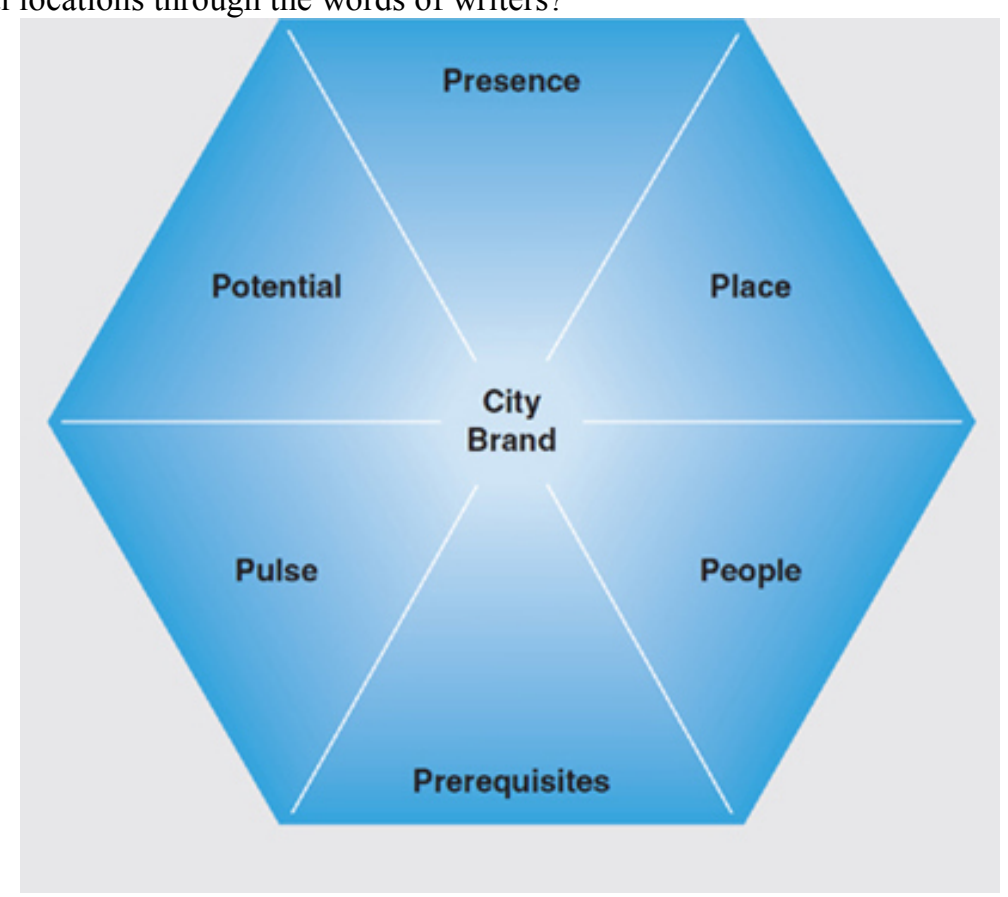

Figure 1. The City Brand Hexagon Model, Anholt, Gfk Roper (2011a)

\section{Methodology}

This paper adopts a textual analysis of the collection of stories, Lagos Noir edited by Chris Abani with 13 collections from various authors including Igoni Barrett, Nnedi Okorafor and Leye Adenle. Selecting a sample from 13 stories enabled efficient management of data, hence using purposive sampling, one story per section was selected from the Lagos Noir series. To derive a representative sample, the stories chosen were representative of the Lagos Mainland and Lagos Island. After reading the entire collection of stories, three stories were selected from the three-part table of contents identified in the subsequent section based on the discretion of the researcher. Heaven's Gate is chosen from the first section of the book, Cops \& Robbers, based on the location of the story on the mainland - Ojo. The second story analysed for this study is The Swimming Pool by Sarah Ladipo Manyika is located in Victoria Island which is located on Lagos Island. The third story chosen for this study is Uncle Sam authored by Leye Adenle situated at the Murtala Mohammed Airport, a major location for the city as it is the International Airport for Lagos State, located in Ikeja on the mainland.

After the first reading of the 13 stories, a second reading of the three stories chosen for this study, Heaven's Gate, The Swimming Pool and Uncle Sam were read a second time. Sticky notes were used in highlighting sections of the book that highlighted any feature of Lagos city in terms of public facilities, employment, the people of the city, tourism amongst others. After this initial analysis, the various sections highlighted were examined and categorized according to the categories in the city brand hexagon - Presence, Place, Prerequisities, People, Pulse and Potential. These themes formed the measurement metrics used in the analysis for this research.

\section{Content Analysis of selected stories}

In this section, the analysis of the three stories, Heaven's Gate, The Swimming Pool and Uncle Sam will be discussed; 


\subsection{Analysis of the Story, Heaven's Gate}

While this 12-paged story covers various areas in Lagos, Ojo has been selected as a key location by the author. Ojo is located in the Mainland area of Lagos and a key landmark of this local government in Lagos is the Lagos State University, which is subtly featured at the end of the story. In this story, Heaven's Gate written by Chika Unigwe, the search for a better life is the theme as Emeka, an indigene of a South Eastern state, Enugu migrates to Lagos for a better life to enable him to support his family in the village. After taking a job as an Okada (motorcycle) rider in the city of Lagos, his dreams remain unfulfilled as he is eventually killed during a bribegone-wrong scenario by the same policemen who should protect him. The key themes observed in this story related to Lagos city are highlighted below;

\subsubsection{Lagos, the Land of Opportunity}

The desire for a better life is a major reason for individuals and families migrating from other parts of Nigeria to Lagos despite the challenges of urban life. In this story, Emeka leaves his town, Enugu and comes to Lagos, "the only city where dreams could be pursued..." (Unigwe, 2018), to start the same job he has in Enugu (Okada driving)to be able to provide for his family. With a huge population, transportation is a money-making venture in Lagos, buses, motorcycles hailing services, tricycles, car-hailing services and ferries are a key public means of transportation (AFD, 2011; Otunola, Kriticos, \& Harman, 2019). A few weeks into his job, Emeka is making enough money to send back to his widowed mother and brother and save for his apartment in Lagos. Such "quick" success stories are passed by word of mouth to family members in towns and villages, just as Emeka heard about his friend, Ifeatu's success in Lagos as a pure-water manufacturer. However, the dreadful stories of city living are rarely passed on to unsuspecting national migrants. Compared to his job as a motorcycle rider in his village, Emeka has to acquire guts (insulting other drivers and driving roughly) and pick up passengers at late hours of the night to hit his daily quota and it is on one of such trips that he meets his deadly end at the hands of policemen.

\subsubsection{Lagos Love Versus Enugu Love}

Another key theme in Heaven's Gate is the difference between relationships in the city and in towns. The author emphasizes the persona of the "city girl" and associates it with freedom, unabashedness and open relationships with the opposite sex. In describing a "Lagos girl", one of the characters, Ifeatu, who also migrated to Lagos in the search for a better life, has plans to go back to the village to build a house and marry someone from his town rather than from Lagos as he states "None of these Lagos girls, ooo. Their eyes are too open" (Unigwe, 2018). However, while the characters prefer to marry ladies from their village, it does not mean Lagos ladies do not make "good girlfriends". And just like his friend, one of Emeka's wishes asides from getting his own apartment, is to keep a Lagos girlfriend who he describes thus, "a Lagos girl, with hair extensions down to her buttocks; those girls who were as bold as men - Ifeatu said- in bed". These "Lagos girls" are not seen as marriageable, as Unigwe (2018) adds " a beautiful girl he could not take home to his mother, but one who would open all the joys between the thighs of Lagos to him." As the plot thickens, Emeka finds comfort in a Lagos girl, Sikirat and the author shows the difference between the Emeka's Lagos girlfriend and Enugu girlfriend. While Sikirat exercises boldness in responding to Emeka's wooing and sexual advances, his ex-girlfriend in Enugu is portrayed as being naïve in sexual experiences and making the first move.

\subsubsection{Lagos Driving is for Madmen}

Lagos city is popular for traffic congestion and rough driving. As a travel blogger, Sassy Funke notes, "You think you are a pretty good driver, right? You may have driven on all the roads and highways in the world but if you haven't driven in Lagos, you simply haven't driven at all...I can categorically say that driving in Lagos is the true test of a real driver" (Sassy Funke, 2020). The impatience of the drivers in the city further adds to the traffic congestion (City Monitor, 2015) and Unigwe (2018) describes Lagos drivers as those "who drove like madmen"(Unigwe, 2018). The author brings the transportation situation of Lagos to life by showing the evolution of Emeka from an Enugu Okada driver to a Lagos Okada driver who "shed his inhibitions. He drove as maniacally as his colleagues did and hurled insults at other drivers in proper Lagos fashion..."(Unigwe, 2018). In his first few weeks with his motorcycle, Emeka considers dropping the trade for fear of losing his life, however, in a few weeks, he adopts the same recklessness and flouting of driving rules in traffic-ridden Lagos. Hurling insults is also part of the "unwritten" driver rules as he soon joins the bandwagon of Lagos Okada drivers in this culture synonymous with motorcycle drivers in Lagos city. Presently, transportation in Lagos is still in need of restructuring, buses, boats, tricycles and motorcycles are key channels of public transport, except for those who own private cars, however, they are still substandard and not optimized to support the increasing population in the city (Otunola, Kriticos, \& Harman, 2019).

5.1.4 The Third Mainland is an Economic Bridge Linking Lagos Mainland and Lagos Island

Socio-economic inequalities guide the geographical division of the city of Lagos, which is divided mainly into Lagos Mainland and Lagos Island connected by the Third Mainland bridge, also known as the second-longest bridge in Africa (City Monitor, 2015). The Island is more swanky than the Mainland, with properties and leisure facilities costing twice as much when compared to other areas in the Mainland. Consistently, the media has 
enforced an identity to symbolize the difference between the Lagos Mainland and Lagos Island. Lagos Island has been positioned as the entertainment and fashion capital of the city and is more expensive to live and to shop when compared to the mainland. The Island is also the location of global companies and upscale neighbourhoods such as the popular Banana Island and the emerging Eko Atlantic City (Salaudeen, 2018). This aspect of the city features in this story, one of the characters, Reverend, who provides Emeka with his Okada in exchange for daily payments speaks about moving his location from the Mainland to the Island. Reverend says "Everybody keeps saying I should move. Buy a house in Victoria Island or Banana Island - somewhere more upscale. I ask them, why should I move? Why move when my constituency is here....” (Unigwe, 2018).

\subsubsection{Dark Lagos}

While Lagos continues to appeal to others as a place of opportunity, the city has its dark side. The metropolis is also home to overcrowded slums, high levels of unemployment, lawlessness, crime and poverty (Agbola, 1997). After Emeka is killed by policemen - the same people employed to protect him - due to a bribe situation gone wrong. A good Samaritan finds his lifeless body on the Mainland, even though the crime happened on the Island part of Lagos, yet when she tries to report the case to the police, they ask her to mind her business or face arrest. Insecurity and police brutality are key issues that have been identified as key risks in the city of Lagos and continue to be a threat to the "limitless opportunities" offered by the city to its stakeholders.

\subsection{Analysis of The Story, The Swimming Pool}

The story, The Swimming Pool is 8 pages long and is set against the plush background of high-brow, Victoria Island in Lagos. It is focused on the wealthy Mr Luke Adewale and some of the drama ongoing in his household and a disagreement between his teenage daughter, which eventually leads to his death. Mayinka (2018), starts the story with a concern for climate change in the megacity of Lagos, "Speaking of oceans, Victoria Island is slipping into the Atlantic, but nobody wants to know. People have other, more pressing things to worry about." The key themes observed in this story related to Lagos city are highlighted below;

\subsubsection{Victoria Island: The Super-Rich side of Lagos}

The author reiterates the stark contrast between the socio-economic groups and the prevalent situation of urban poverty in Lagos. The character, Mr Adewale has a swimming pool in his backyard and a retinue of staff including a maid, driver, security guards and gardeners. Mr Adewale has the financial resources to send his daughter, Tinuke, to a boarding school abroad and 17year old Tinuke also has a male teenage friend who picks her up for a hangout at prominent, Eko Hotel with his father's Range Rover. Yet in the background, there is the character of their cook, Cecilia with lesser means, scheming to steal from her employers, to access a better life. Statistics show that as of 2020 , Lagos had an $8.5 \%$ poverty rate with about 300,000 homeless people and yet the population growth is still rated at 3.44\% in 2021 (Nwogu, 2021). The housing situation has been described as a "menace to health and to human dignity" by the United Nations (Agbola, 2017) with poorly built structures and residents living in unhygienic conditions with little access to clean water. Lagos is full of bipolar opposites, the city is home to the multi-billion dollar prime estate, Eko Atlantic city (Ajibade, 2017), which has been described as the "new Lagos" and is also home to slums such as Makoko (a popular fishing community with homes built on wooden stilts) and Ajegunle, also referred to as the "jungle city" and the most populous slum in Lagos city (Afun-Ogidan, 2019; Olajide, 2010). Another notable feature in this story is the mention of a tourist attraction, popular Eko hotel, however, the author did not emphasize the hotel's features or portray it as a tourist attraction except for the mention of a pool.

\subsection{Analysis of The Story, Uncle Sam}

The Murtala Mohammed Airport is the backdrop of this 10-paged story based on "419" and internet scams. The synopsis is centred around a British citizen, Dougal who travels to Nigeria, after receiving a legitimate call from a Nigerian chief who informs him of his inheritance from a long-lost Uncle. However, when he gets to the airport, he gets scammed into believing that the previous correspondences are a scam and in conjunction with a Nigerian, another foreigner takes on his identity and advances to claim his inheritance.

The key themes observed in this story related to Lagos city are highlighted below;

\subsubsection{Welcome to Lagos}

Airports are the gateway for visitors including tourists and investors to get a sense of a city and global city administrators are positioning their airports as status symbols for their cities (Halpern \& Graham, 2013; (Metropolis, 2017). Yet, the Murtala Mohammed International airport (MMIA) in Lagos, seems to lack the pomp and pageantry symbolic of an international gateway. Basic features popular in other global airports such as adequate sitting areas and air-conditioning are lacking. As the author of Uncle Sam, Adenle (2018), notes "He found a tall, free-standing air-conditioning unit whirling out air from dirty vents...". The weather in Lagos is common to tropical regions and has humid weather most of the year, yet the airport does not seem to be managed to meet up with global standards. In their study focused on evaluating airport service quality in Nigeria, Chinonso \& Ejem (2020), conclude that both local and foreign passengers rank the MMIA low across all levels 
for service quality and there have been complaints about overcrowding, malfunctioning elevators, lack of innovative technologies and inadequate seating arrangements for travellers (Ojo, 2014).

5.3.2 419 Lagos

Since the 1980s, Nigeria has consistently gained negative publicity for scams. The digitization era gave rise to cyber-crime syndicates known as the "Yahoo Yahoo". The results of a web search of the keyword "Nigeria", in addition to revealing "things to do in Lagos", may also reveal news and reports on 419 scams and security alerts. Before his trip to Nigeria, the wife of the story's protagonist, Dougal researches Nigeria on the internet, and rather than print out stories on global academic achievements of Nigerian students, tourist attractions, friendly residents, she "printed out dozens of stories about Nigerian fraudsters - 419, they call them" (Adenle, 2018). The country brand rubs off on its host cities and vice versa, Lagos is Nigeria and Nigeria is Lagos, and this is why the branding of a country is as important as the branding of its host cities. The 2020 travel advisory report by the U.S Department of State assesses Nigeria at level 3, signifying that interested visitors should reassess their travel due to reasons such as "crime, terrorism, civil unrest, kidnapping and maritime crime" (OSAC, 2020). In this report, they go further to highlight the prevalence of cyber-crime in Nigeria, "Cybercrime has become a concern and is becoming more sophisticated..." (OSAC, 2020).

\section{Discussion and Findings}

The city brand hexagon was applied to this research, to understand the portrayal of Lagos city in Lagos Noir, looking through the lens of the three stories chosen for this study.

\subsection{Presence}

The Noir series is a niche genre that focuses on the "dark" aspects of a city. Therefore, it is obvious in the three stories used as a case study, that there will be no glorification and emphasis on the positive aspects of this city, after all this is Lagos Noir. There is little focus on the positive aspects of Lagos city and how it compares to other global cities in areas of culture, governance and economic scale. Climate change is of concern in "The Swimming Pool", where the author reiterates that Victoria Island is flood-prone, yet the rich continue to expand to these areas and build empires and residences in this area. Urban planning is still a challenge in Lagos and in previous years, the city has experienced flooding in both its pricey and slum settlements. By 2100 , it is predicted that there will be a significant rise in sea levels, leading to more flooding and erosion (Johnson, 2021).

\subsection{Prerequisities}

The sound of generators is popular in Nigeria, not just Lagos, as the erratic electricity supply has led to the dependence of residents on candles, lanterns, generators and solar-powered solutions. In the story, "The Swimming Pool" Mr Adewale continually whines about the neighbour's noisy generators despite living in the suburb area of Victoria Island. The national challenges are common to the city and Lagos shares the Nigerian burden - Nigeria ranks 152th out of 157 countries in the World Bank 2018 Human capital index and the country still lacks sufficient infrastructure and effective institutions despite being the largest oil exporter in Africa (The World Bank, 2020).

As an economic capital, the airport is a key entry point for visitors travelling by air into the city. However, in the story, Uncle Sam, the sub-standard facilities at the Lagos airport, MMIA is put on display for readers.

\subsection{People}

In Lagos Noir, the people of Lagos are represented as diverse but there is also a constant emphasis between the super-rich and the poor, in the three stories that form the case study for this paper. Lagos is originally home to the Aworis, a group of Yorubas but has since become home to all Nigerians and foreigners alike (Agbola, 1997). The protagonist in "Heaven's Gate" is not an indigene of Lagos State, but hopes to find a home in Lagos to make money and send to his family in Enugu. In the story, "Uncle Sam", Dougal's sponsor, Chief Ernest Abraham Okonkwo II is from the South-East of Nigeria, even though he lives in Lagos.

The city of Lagos as earlier established is also a reflection of Nigeria. Adenle (2018) notes the impatience of Nigerians which can also apply to residents of Lagos, he notes "Nigerians brushing past him with their bulging hand luggage and their unapologetic impatience." This impatience is evident in "Heaven's Gate", as Emeka navigates the hostile streets of Lagos amidst traffic and frustrated, insulting drivers. Yet, amid this impatience is the strive to make better out of situations. The city has been tagged "city of hustle" for their consistent creativity and effort in making the best of the worst situations (Mitter, 2019). "Loving in Lagos" is also another theme that Unigwe (2018) emphasises in Heaven's Gate, showing the difference between the boldness and street-wise behaviour of city ladies and the shy naivete of town ladies.

\subsection{Pulse}

Eko Hotel and Sheraton Hotel is featured in "The Swimming Pool" and "Uncle Sam" respectively as choice 
accommodation for visitors and residents alike. However, they are located in the High brow areas and it is obvious that a lot of such locations are located in Lagos Island. Since the Noir series is focused more on the chaos in the city than positive aspects, "Uncle Sam" highlights the deficiency of the Murtala Mohammed Airport, an international gateway that should celebrate the city and not taint its image to first-time visitors. It is through the lens of this international airport that Nigeria is viewed by visitors and residents alike.

\subsection{Potential}

Despite, the "dark" theme of Lagos Noir, it is obvious that Lagos is a land of opportunity. There is money to be made in the city and it is the promise of an inheritance that brings a British schoolteacher like Dougal all the way from England, to claim the riches of a dead relative and the promise of a better life for his family. It is also the search for a better life, that attracts Emeka to Lagos from Enugu. In a city where urban poverty is on the rise, $\mathrm{Mr}$ Adewale makes enough money to send his daughter Tinuke abroad for Secondary school education. There are immense opportunities in Lagos for investors and business people alike, as global giants such as MTN, Total, and is headquarters to Nigeria's silicon valley for locally grown companies such as Interswitch, Paystack, and Flutterwave (Adeoye, 2021). However, more opportunities can be better explored and utilised to make the business environment in Nigeria friendlier for MSMEs and investors. In early 2020, out of 190 countries, Nigeria ranked 131 on the World Bank list for ease of doing business compared to Rwanda which ranked $38^{\text {th }}$ ( (Munshi, 2021; World Bank Group, 2020).

\section{Conclusion}

As the common saying goes, books open windows to the world. Sometimes, the only vision and relationship built between a person and a place is a book. These books, including fictional writings, mostly draw on the realities of the city and set their characters in an environment that already exists. The city in literature is mostly reflective of the city in reality and the focus should not be to hide these realities, but for city stakeholders to put more effort into changing the negative realities and emphasizing positive features of their cities.

This study shows that the representation of Lagos in Lagos Noir is a reflection of certain aspects of the city of Lagos and Nigeria as a whole. Therefore, city branding is as important as the branding of the nation, and from the findings of this research, Lagos is a reflection of Nigeria and vice versa. Collaborative efforts amongst all stakeholders on a national and state level will further boost the economy and tourism potential of Nigerian cities. There is a huge opportunity for cities to interact with their stakeholders through literary text. However, cities are better positioned when the realities in their environment are positive. This creates some sort of literary tourism, allowing a relationship between the city and its stakeholders and prompting some visitors to expand their experience by visiting countries or cities of their favourite characters.

\section{References}

Adeoye, A. (2021, July 16). Lagos finally grows into its role as Africa's Silicon Valley. Retrieved August 8, 2021, from Rest of World: https://restofworld.org/2021/tech-hubs-lagos/

Agbola, T. (1997). Lagos: A Socio-economic Profile of Selected neighbourhoods. In T. Agbola, The Architecture of Fear: Urban Design and Construction Response to Urban Violence (pp. 43-55). Lagos: IFRA-Nigeria. Retrieved from https://books.openedition.org/ifra/498?lang=en

Ajibade, I. (2017). Can a future city enhance urban resilience and sustainability? A political ecology analysis of Eko Atlantic City, Nigeria. International Journal of Disaster Risk Reduction, 85 - 92.

Akande, L. (2016). Representations of the city in the early and recent Nigerian novel: People of the city and Alpha song. Unilag Journal of Humanities, 3(2), 1-16.

Akashic Books. (2021). About Us. Retrieved February 9, 2021, from Akashic Books: http://www.akashicbooks.com/about/

Akingbe, N., \& Akwen, C. T. (2019). Sanity amidst chaos: Navigating the Lagos cityscape in Nigerian poetry. Imbizo: International Journal of African Literary and Comparative Studies, 10(1), 1-22.

Bjorner, E. (2013). International positioning through online city branding: The case of Chengdu. Journal of Place Management and Development, 6(3), 203-226.

Bruzzi, S., \& Gibson, P. C. (2004). 'Fashion is the fifth character': Fashion, costume and character in Sex and the City. In K. Akass, \& J. McCabe (Eds.), Reading Sex and the City (pp. 115-129). London; New York: I.B Taurus.

Carroll, T. (2016, May 20). Reading the literary city. How urban spaces shape the books we read. Retrieved February 4, 2020, from Literary Hub: https://lithub.com/reading-the-literary-city/

City Monitor. (2015, September 21). In Lagos, the traffic jams can add four hours to your commute. Retrieved August 8, 2021, from City Monitor: https://citymonitor.ai/transport/lagos-traffic-jams-can-add-four-hoursyour-commute-1406

Emordi, E., \& Osiki, O. (2008). Lagos: The "Villagized" city. Information, Society and Justice, 2(1), 95 - 109. 
French, P. (2020, July 20). Lagos: Africa's capital of Noir. Retrieved February 9, 2021, from Crime Reads: https://crimereads.com/lagos-africas-capital-of-noir/

Ghetau, L., \& Esanu, L. (2011). Literary tourism as a promoter of cultural heritage. Sustainable Development and Planning 2011, 150, 345 - 353.

Iduma, E. (2020, June 2). Cyprian Ekwensi's Lagos Noir. Retrieved February 10, 2021, from The New York Review: https://www.nybooks.com/daily/2020/06/02/cyprian-ekwensis-lagos-noir/

Johnson, A. (2021, January 22). How Africa's largest city is staying afloat. Retrieved August 14, 2021, from BBC: https://www.bbc.com/future/article/20210121-lagos-nigeria-how-africas-largest-city-is-staying-afloat

Kia, a. A., Latifi, G., Rasooli, M., \& Kazemnia, M. E. (2016). The role of the mass media in urban management (Case study: 22-district of Tehran municipality). A quarterly Journal of Urban Economics and Management, $4(16), 115-126$.

Makmun, M. T., \& Nuraeni, A. (2018). New York, New York: The Empire State of Mind. Malaysian Journal of Communication, 34(3), 314 - 325.

Malone, T. (2018, April 30). City as Character. Retrieved September 25, 2021, from Lapham's Quarterly: https://www.laphamsquarterly.org/roundtable/city-character

Marcus, R. (2018, June 2). Book Review: "Lagos Noir" edited by Chris Abani. Retrieved August 10, 2021, from Seattle PI: https://www.seattlepi.com/lifestyle/blogcritics/article/Book-Review-Lagos-Noir-Edited-byChris-Abani-12963718.php

Metropolis. (2017). The marketing and branding of Airport areas/ Aetrotropolis. Paris: IAU.

Mitter, S. (2019, February 8). Lagos, City of Hustle, Builds an Art 'Ecosystem'. Retrieved August 14, 2021, from The New York Times: https://www.nytimes.com/2019/02/08/arts/design/lagos-nigeria-art-X-art.html

Munshi, N. (2021, February 1). How Lagos loses out in battle for investors. Retrieved August 14, 2021, from Financial Times: https://www.ft.com/content/eca6f672-4ee6-4dd0-94c4-9213294b61fb

Nwogu, P. (2021, February 2). A report on poverty rates in Lagos State. Retrieved August 8, 2021, from TwentyTen Daily: https://twentytendaily.com/a-report-on-poverty-rates-in-lagos-state/

Ocran, N. (2014, July 31). Nigerian literature: A Lagos reading list. Retrieved February 10, 2021, from Virgin Atlantic: https://blog.virginatlantic.com/nigerian-literature-a-lagos-reading-list/

Ojo, T. K. (2014). Users' perceptions of service quality in Murtala Muhammed. Journal of Marketing and Consumer Research, 3, 48-53.

OSAC. (2020). Nigeria 2020 Crime \& Safety Report: Lagos. Washington: OSAC.

Otunola, B., Kriticos, S., \& Harman, O. (2019). The BRT and the danfo: A case study of Lagos' transport reforms from 1999-2019. IGC Cities that Work Case Study. Lagos: International Growth Centre. Retrieved from https://www.theigc.org/wp-content/uploads/2019/10/lagos-BRT-case-study.pdf

Pasari, P. (2015). "The White Tiger" on half baked India and social and political deterioration. IOSR Journal of Humanities and Social Science (IOSR-JHSS), 20(5), 1-6.

PopulationStat. (2021, August 9). Lagos, Nigeria Population. Retrieved August 9, 2021, from PopulationStat: https://populationstat.com/nigeria/lagos

Salaudeen, A. (2018, June 25). Banana Island Lagos, Nigeria's most exclusive estate. Retrieved August 12, 2021, from Stears Business: https://www.stearsng.com/article/banana-island-nigerias-most-exclusive-estate

Sassy Funke. (2020, March 2). The Lagos chronicles: Driving in Lagos (Know the 10 rules). Retrieved August 12, 2021, from Sassy Funke: https://sassyfunke.com/driving-in-lagos-know-the-rules/

Shringarpure, B. (2020, September 15). Noir books depict East African cities. Retrieved February 10, 2021, from New Frame: https://www.newframe.com/noir-books-depict-east-african-cities/

Spinks, R. (2016, October 6). Cities are built with language: How poetry feeds on urban life. Retrieved 2 4, 2020 , from The Guardian: https:/www.theguardian.com/cities/2016/oct/06/cities-poetry-urban-language-nationalpoetry-day

The World Bank. (2020, November 3). The World Bank in Nigeria. Retrieved from World Bank: https://www.worldbank.org/en/country/nigeria/overview

Unigwe, C. (2018). Heaven's Gate. In C. Abani (Ed.), Lagos Noir (pp. 41-53). Abuja; London: Cassava Republic.

Wellington, B. (2010, January 5). Banky W. - Lagos Party (Brand new official video). Retrieved July 31, 2021, from Youtube: https://www.youtube.com/watch?v=YiSX5pagz8s 